and yet think we might do something to help forward the good cause by co-operating with others.

The immediate objects of such an association should be in my opinion (I) To collect and distribute information connected with the subject; (2) To induce examining bodies to frame their questions in geometry without reference to any particular tertbook.

Iring Edward's School, Birmingham

RAWDON LEVETT

\section{Philology and Darwinism}

Mr. FARRAR's interesting communication on this subject in a recent number of NATURE, suggests to me a few remarks. As one who has paid considerable attention to the various dialects existing throughout Scotland, as well as to the manner in which our Gaelic-spealking population is by stern necessity obliged to attempt the pronunciation of Anglo-Saxon words, I have become thoroughly convinced that the growth, life, and death of languages are subject to fixed laws. The Highlander whom $\overline{\mathrm{I}}$ meet and who tells me this is a "Koot tay" is as unconsciously obeying Grimm's law of the transposition of consonants as the sun above him is obeying Newton's law of gravitation.

There is this difference, however, between Mr. Darwin's teachings regarding animals and the changes of language, that whereas those animals whose breeding and training are most subject to man's conscious action exhibit the greatest amount of variability, those dialects which are the most reglected and despised by educated men, and which, in this respect, may be called the weeds of speech, are far more variable than Queen's English, watched over as the latter is by such a host of schoolmasters, lexicons, and grammars. The difference of pronunciation of the same words in different counties is great, while many words in the dialect of one county are quite unknown in that of another, in this respect presenting a striking analogy to the Flora of the country. Even in words formed from sound, in which case, at first thought, we might expect considerable uniformity, the difference is often very marked, as between Scotland and England. The words imitative of the animal voice, or of the different cries of the same animal under different sensations are sometimes unlike, for the horse neighs and the cat mews in England, whereas they respectively nicher (ch guttural), and nyioo in Scotland. Sometimes the initative word is from the so:tnd of different organs, as lapwing in English from the flap of the wing; peervit in Scotland from the sound of the voice. Generally people so ignorant as to be necessitated always to express their thoughts in a rustic dialect, do so with the assistance of more or less gesture, and even this gesture is not quite whimsical, but has family and county resemblances. In conclusion, my impression is that the dialects which run wild are much more variable than those under man's care, which is the reverse of the case with wild and domestic arimals and plants.

S. J.

\section{Xanthidia in Flint}

DR. CARPENTER, in his recent lecture at the Royal Institution on "the Temperature and Animal Life of the Deep Sea," speaks of the resemblance of the globigerina mud to chalk as being "greatly strengthened by the recognition of several characteristically cretaceous types among the foraminifera scattered through the mass of globigerina, of which it is principally composed ; as also of the Xanthidia frequently presented in fint. (NATURE, vol, i., p. 564.)

The precise nature of the spinous orbicular bodies found in flint, and generally called Xanthidia, has hitherto been a matter of some doubt. Ehrenberg described them as fossil species of his genus of supposed polygastric animalculre, Xanthidium. Their structure, however, differs in many respects from true Xanthidia, which form a genus of Desmidiece, now universally admitted to be vegetable organisms, and, like nearly all desmids, having compressed bipartite cells, whilst the fossils have globose and entire cells. The most recent opinion has been that they are the fossil sporangia of other species of Desmidiea, and they do indeed bear considerable resemblance to the sporangia of varions species of the genera Micrasterias, Euastrum, Staurastrum, Cosmarium, and Closterizm. An objection to this opinion arises from the fact that Desnitidic $a$ are (so far at least as at present ascertained) exclusively fresh-water plants, and do not appear at all adapted for a deep-sea existence; whereas on the other hand, the chalk containing the flints may now be said to have been conclusively proved to have been formed at a considerable depth at the bottom of the sea : and the other organisms with which the fossils in question are found associated are un: doubtedly marine.

The discovery of these Xanthidia (?) then, at an ocean depth of 767 fathoms, is a most important fact, whatever their nature may be; what that nature is, I, and I doubt not many others of your readers, would be glad to learn from Dr. Carpenter, or others who have had an opportunity of seeing the specimens he alludes to.

Winchester, May I4

Fred, J. Warnek

\section{What is a Boulder?}

WitH all terms in ordinary use there is a looseness of meaning, which, while not in the least degree inconvenient in common language, becomes so when transferred to the would-bc-exact nomenclature of science.

Hobbes says, "A name is a word taken at pleasure to serve for a mark which may raise in our own mind a thought ; like to some thought we had before, and which being pronounced to others may be to them a sign of what the speaker had or had not before in his mind."

It is obvious, however, that a name pronounced by a speaker, or written by an author, can only raise, in the minds of others, the proper thought, when the exact meaning of such a name has been agreed upon by those who make use of the name; and it appears to me desirable that in all cases when names in common use are transferred to the language of science, their exact meaning should be stated. In some sciences, as in botany, this is done, where such terms as leaf, stem, root, \&c., are defined apart from their ordinary signification, but much remains to be done in this way. Thus, take the query at the head of this letter. I have tried to find out exactiy what a boulder is, and I completely fail. According to Dance a boulder is " a mass of rock, whether rounded or not, which has been transported by natural agencies from its native bed." This definition is excellent at first sight, but it fails, as the term "mass of rock" conveys no clear idea as to size. Ask half-a-dozen persons the smallest size they would attribute to a mass of granite, and the answers would vary considerably. One cannot see why the smallest piece that would contain the constituents of the rock should not be called a mass, and in that case many of the large grains of sand on a granitic coast would be included in the term "boulder." But this is absurd, for we might then speak of carrying half a dozen boulders in the waistcoat pocket, or a geologist might suffer from having a boulder blown accidentally into his eye ! There is apparently no determinate size at which a boulder begins or ends; but it seems to me desirable that some idea of size included should be given in the definition, and I would ask some of your readers to be good enough to state what they understand by a "boulder," with a view of getting an exact idea of the meaning of this frequently used term.

Midland Institute, May 9

C. J. WOODWARD

\section{The Anglo-Saxon Conquest}

A CORRESPONDENT, writing under the signature "A. Hall," in your issue of last week, suggests that in laying certain statistics as to the longevity of the Romano-Britons before the Royal Institution, I had "forgotten that the youth of Romano-Britain had for many generations been forcibly expatriated, drafted abroad to feed the armies of Imperial Rome." Your correspondent "appears to have forgotten " what the résumé of my lecture stated, viz., that my observations related to the time of Cerdic; and he will now no doubt recollect that a space of about three generawill now no doubt recollect that a space of about three which he tions intervened between this period and the one to when to allow of the balance which the Romano-British population is supposed to have suffered by being drafted into the Roman armies, righting itself.

$I$ have, in a memoir which the Society of Antiquarians has honoured me by publishing in the "Archæologia" of this year, given other reasons, and these at greater length, for holding the explanation which your correspondent suggests for my statistics to be erroneous. I do not in that memoir quote, in illustration of and as a means of expressing that explanation, some lines from Mr. Henry Lushington's poem "Inkermann." These lines I did quote in my lecture, and will quote them here, as they may 